\title{
A P-T-composition cross-section of spinel and garnet facies lithospheric mantle in the Minusa region SW of the Siberian craton.
}

Malkovets, V.G. ${ }^{1}$, Ionov, D.A. ${ }^{2}$, Griffin, W.L. ${ }^{2}$, O'Reilly, S.Y. ${ }^{2}$, Pokhilenko, N.P. ${ }^{1}$, Litasov, K.D. ${ }^{1}$

1. Institute of Mineralogy and Petrography, Siberian Branch, Russian Academy of Sciences, Novosibirsk, 630090, Russia

2. GEMOC, School of Earth Sciences, Macquarie University, Sydney, N.S.W. 2109, Australia

Garnet-spinel and spinel peridotite and pyroxenite xenoliths from three upper Cretaceous basanitic pipes in the Minusa region, southern Siberia (Malkovets et al., 1997) provide sampling of the upper mantle in a mobile belt near the southwestern boundary of the Siberian craton. A P-Tcomposition lithospheric cross-section has been constructed based on a detailed electron microprobe study of representative xenoliths and laser ablation ICP-MS analyses of their clinopyroxenes and garnets.

Both garnet-spinel and spinel lherzolite xenoliths have been found in the Tergesh pipe. The lherzolites commonly have moderate to high clinopyroxene (cpx) contents and protogranular texture. The garnet contents in the garnet-spinel lherzolites are low and garnet grains typically have finegrained reaction rims of orthopyroxene and spinel $( \pm \mathrm{cpx})$. T-P estimates using a combination of the Ca-in-opx thermometer of Brey and Kohler (1990) and Nickel and Green (1985) barometer define an elevated geothermal gradient with fairly low $\mathrm{P}$ estimates of 16-18 kbar for the garnet-spinel lherzolites. These $\mathrm{P}$ estimates are lower than for garnet and garnet-spinel peridotites in other basalthosted xenolith suites from southern Siberia ( Ionov et al., 1993) and are similar to those in the SE Australian geotherm (O'Reilly and Griffin, 1985).

Garnet-spinel and spinel lherzolites from-Tergesh yield a fairly narrow $\mathrm{T}$ range of 1030$1070^{\circ} \mathrm{C}$. Clinopyroxenes in the majority of Tergesh lherzolites have HREE, $\mathrm{Sr}$ and $\mathrm{Y}$ content typical of fertile mantle peridotites, with high levels of HREE and slight to mederate depletions in LREE, $\mathrm{Th}, \mathrm{U}$ and $\mathrm{Nb}$ (Fig. la). The $\mathrm{La} / \mathrm{Yb}_{\mathrm{n}}$ and $\mathrm{La} / \mathrm{Sm}_{\mathrm{n}}$ ratios range from an almost primitive 0.9 to slightly depleted 0.6-0.4.

Only spinel lherzolites have been collected from two other pipes, Krasnoozersk and Kongarovsk. Most of them have protogranular textures whereas some are foliated. The temperature range for peridotites from these two pipes $\left(910-1050^{\circ} \mathrm{C}\right)$ is wider than that for the Tergesh lherzolites, with the majority of samples yielding lower $\mathrm{T}$ values below $1010^{\circ}$. Most xenoliths have HREE and $Y$ contents in cpx close to those for the Tergesh xenoliths, but in all the samples the cpx are enriched in LREE, Th, $\mathrm{U}$ and $\mathrm{Sr}$ and show negative $\mathrm{Nb}-\mathrm{Ti}-\mathrm{Zr}$-Hf anomalies (Fig $2 \mathrm{~b}$ and $2 \mathrm{c}$ ) relative to adjacent REE. $\mathrm{La} / \mathrm{Yb}_{\mathrm{n}}$ and $\mathrm{La} / \mathrm{Sm}_{\mathrm{n}}$ ratios range from 2 to 10 and from 0.5 to 7 respectively. Pyroxene grains in protogranular xenoliths show consistent zoning patterns with $\mathrm{Ca}$ and $\mathrm{Al}$ in orthopyroxene increasing towards the rims and $\mathrm{Ol}$ rims strongly enriched in $\mathrm{Ca}$ (up to $0.2 \%$ ).

Besides the mineral zoning, primary parageneses of garnet-spinel lherzolites from the Tergesh pipe have been affected by replacement of garnet by spinel and orthopyroxene coronas due to the reaction: Pyr + Fo $\Leftrightarrow 2 \mathrm{En}$. Sp. Such thermal perturbation appears to have affected the xenoliths before their entrainment in host magma. This suggests an isobaric heating process in the lithospheric mantle in which garnet and garnet-spinel lherzolites re-equilibrated to an elevated geothermal gradient. Such an anomalously high geothermal gradient is thermally unstable and may have developed due to magma underplating shortly before the eruption of the host basanites because 


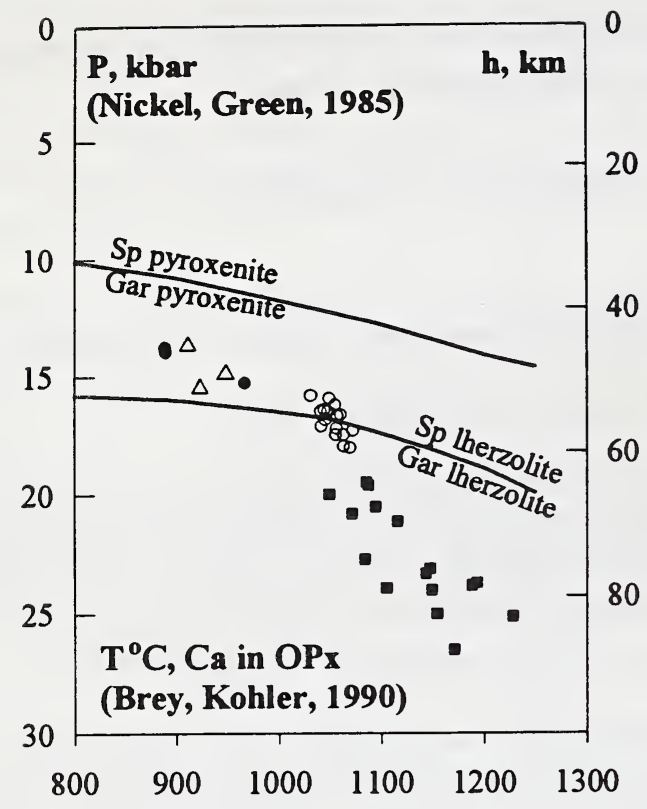

Fig. 1. T-P-estimates for Tergesh pipe garnet-spinel lherzolites.

open circles - Tergesh pipe gar-spl lherzolites, solid circles - Tergesh pipe gar-spl pyroxenites, solid triangles - Krasnoozersk pipe gar-spl pyroxenites,

solid squares - Vitim gar and gar-spl lherzolites (Ionov et al., 1993).

Fig. 2. Normalized (after Hofmann, 1988) abundance pattern diagrams for clinopyroxene and garnet from garnet-spinel and spinel lherzolites.

(a) Tergesh pipe. circles - garnet-spinel lherzolites, squares - spinel lherzolites.

(b) Krasnoozersk pipe.

Spinel lherzolites.

(c) Kongarovsk pipe. Spinel lherzolites.
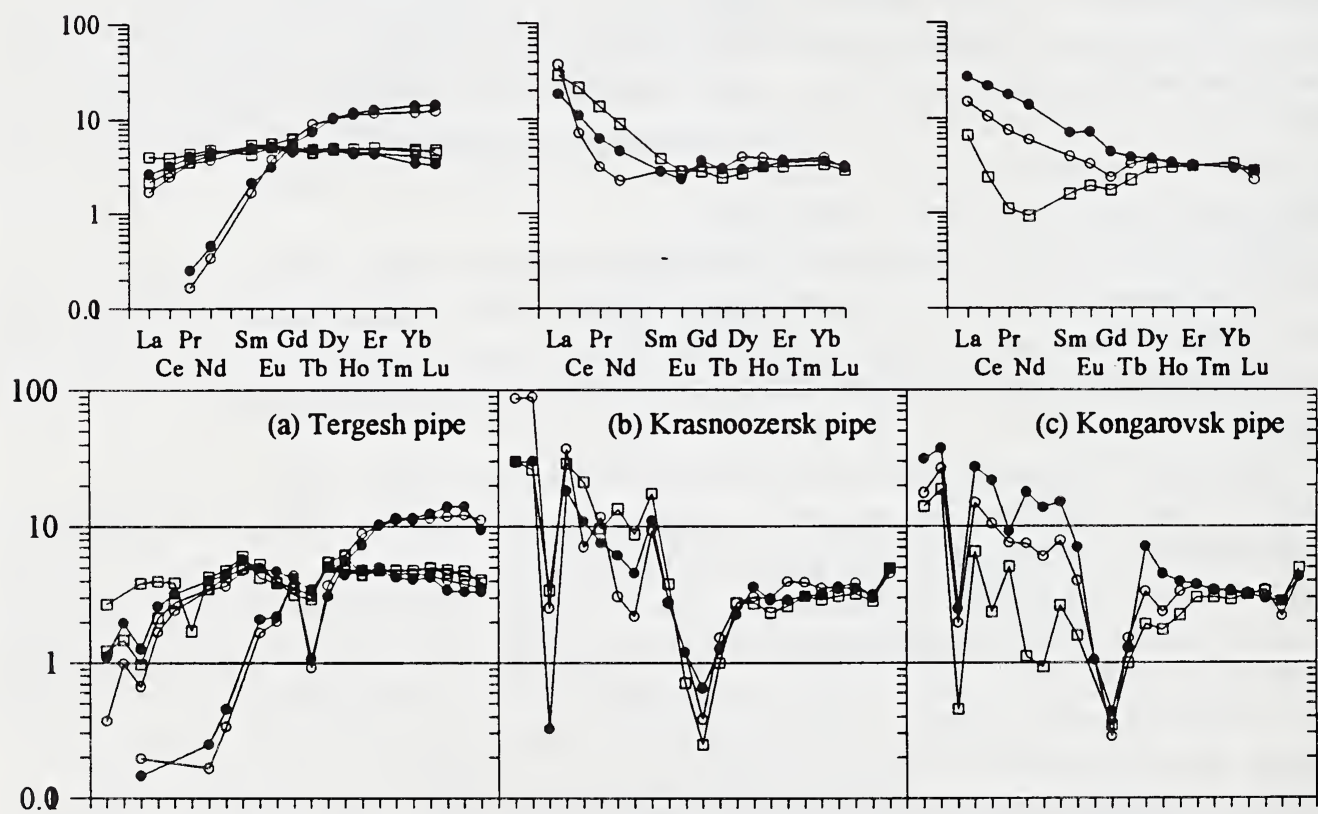

Th NbCe Pr Sr Hf Ti GdDy Y Yb Sc Th NbCe Pr Sr Hf Ti GdDy Y Yb Sc Th NbCe Pr Sr Hf Ti GdDy Y YbSc U La PbNdSm Zr Eu TbHo Er Lu U La PbNdSm Zr Eu TbHo Er Lu U La PbNdSm Zr Eu TbHo Er Lu 
retrograde mineral zoning patterns of major elements with high diffusion rates (e.g. Ca in olivine and orthopyroxene) would have otherwise developed during subsequent cooling.

Our data suggest that the upper mantle in the Minusa region has, at first approximation, a distinct two-level structure.

(a) The deeper garnet-spinel and spinel lherzolites carried to the surface in the Tergesh pipe appear to have nearly fertile modal compositions and slightly depleted trace element patterns. Their modal compositions and mineral chemistry are very different from those in garnet-bearing xenoliths from the Yakutian kimberlites (Boyd et al., 1996). Clinopyroxenes from the garnet-spinel lherzolites have HREE contents similar to those of clinopyroxenes from spinel lherzolites (Fig.2a). This is consistent with low modal content of garnet in the lherzolites reflecting their position in the mantle column near the uppermost level of garnet-spinel lherzolite transition zone (16-18 kbar and 1030$1070^{\circ} \mathrm{C}$, Fig. 1).

(b) The shallow level spinel lherzolites of Krasnoozersk and Kongarovsk pipes are generally less fertile and provide a wider range of cpx contents compared to Tergesh lherzolites. Their clinopyroxenes typically show trace elements patterns with strong LREE and Th, U, Sr enrichments and negative $\mathrm{Nb}-\mathrm{Ti}-\mathrm{Zr}-\mathrm{Hf}$ anomalies indicative of a complex history probably involving depletion events and a number of metasomatic episodes by different metasomatic media.

\section{References}

Brey, G., Kohler, T., 1990, Geothermobarometry in four-phase lherzolites II. New thermobarometers, and practical assessment of existing thermobarometers: J. Petrol., 31, p. 13531378.

Boyd, F.R., Pokhilenko, N.P., Pearson, D.G., Mertzman, S.A., Sobolev, N.V., Finger, L.W., 1997, Composition of the Siberian cratonic mantle: Ezidence from Udachnaya peridotite xenoliths: Contib. Mineral. Petrol., p. 228-246.

Hofmann, A., 1988, Chemical differentiation of the Earth: the relationship between mantle, continental crust, and oceanic crust: Earth Planet. Sci. Lett., 90, p. 297-314.

Ionov, D., Ashchepkov, I., Stosch, H.-G., Witt-Eickschen, G., and Seck, H, 1993, Garnet peridotite xenoliths the Vitim volcanic field, Baikal region: the nature of the garnet-spinel peridotite transition zone in the continental mantle: J. Petrol, 34, 6, p. 1141-1175.

Nickel, K., Green, D., 1985, Empirical geothermobarometry for garnet peridotites and implications for the nature of the lithospere, kimberlites and diamonds: Earth Planet. Sci. Lett., 18, p. 158-170.

Malkovets, V., Travin, A., Litasov, Yu., Litasov K., 1997, Argon-argon dating of basanites from volcanic pipes of North Minusa depression, Khakassia, Russia: Seventh Annual V.M. Goldsmidt Conference, 1997, Tucson, Arizona, USA, p. 130-131.

O'Reilly, S.Y., and Griffin, W.L., 1985, A xenolith-derived geotherm for southeastern Australia and its geophysical implications: Tectonophysics, 111, p. 41-64. 